\title{
Religion in an Oppressive Society: The Antebellum Example
}

\author{
Kingsley N. Okoro \\ Department of Philosophy and Religion, Ebonyi State University, Abakaliki, Nigeria \\ Email: Okoro_kingsleyn@yahoo.com \\ Received July 25 ${ }^{\text {th }}$, 2012; revised August 30 ${ }^{\text {th }}$, 2012; accepted September $10^{\text {th }}, 2012$
}

\begin{abstract}
Religion: a socio-spiritual phenomenon that pervades and influences human actions in all realms of human existences plays diverse and divergent roles in the society. Therefore, it is difficult to define with a simply and a single category. Hence, on the one hand, Karl Marx saw it as an instrument that supports the status quo and oppresses the less privileged and the powerless and as such a vital force in the legitimization of social ills in the society. On the other hand, Marx Webber and other functional theorists maintain that religion as a social fact is a force in mobilizing social solidarity and unified actions against the social order. In this direction religion therefore plays revolutionary roles in any given society. Against the backdrop of the seeming contradicting and conflicting positions of these two main schools of thought in the field of sociology of religion, this paper is poised to re-assess the divergent roles religion has played in history among the oppressed people of the world, using the both Marxian and Webberian paradigms as a matrix. This paper considers oppressive society as a society that maintains a social and economic classification of its members as a norm. It is also noted that it is through such classification of its members in their nexus that social injustice, discriminations, dehumanization are maintained. This situation is the defining paradigm of the global village (the new World Order), governed strictly by economic dictum. To this end therefore, this paper re-invokes the roles religion played in the "Antebellum" America, with a view of applying the same in the modern era, which has great resemblance with the Antebellum America, in terms of oppression, though not in its magnitude.
\end{abstract}

Keywords: Religion; Oppressive; Society; Antebellum

\section{Introduction}

Religion, more especially from the 19th country onwards, has been suspected or rather alleged as having the tendency of supporting the established social order. The idea was suspected also to have been developed and forwarded by Karl Marx. Thus a casual reading of Marx's theory of religion may tend to justify the claim that religion is both a creation and apparatus of the operators of a capitalistic oppressive economic system. However, Marx never made religion the center of his discourse but stumbled at it via the socio-economic analysis of his time and discovered this to be sole purveyor of alienation to the people-(The poor masses). Consequently, his theory of religion has become the benchmark for contemporary social or scientific study of religion. It was Uchegbue (1997) that provided an avid background of Marx theory of religion as he writes:

...Reflecting on the situation of alienation provided by the economic system of his day, the consequent Social conflict produced by the conflicting economic interests of the groups and classes and the inability of the proletariats to protest against the marginalizing conditions of alienation, Marx forms his theory of the origin, essence and role of region (286).

According to Marx, the workers in the exploitative capitalistic society is told that he/she is a replaceable tool, alienated to the point of discontent, in Marx eyes, religion enters this at point. Capitalism, therefore utilizes our tendency towards religion as a tool or ideological apparatus to justify this alienation. Religion (Christianity) teaches that those who gather up riches and power in this life will almost certainly not be rewarded in the next life, while those who suffer oppression and poverty in this life, while cultivating their spiritual wealth certainly will be rewarded in the kingdom of God (Christian, 2008: pp. 1-7) This idea of the role of religion gave birth to Marx definition of religion thus, "Region is the sigh of the oppressed creature, the heart of a heartless world, just as it is the spirit of the spiritless situation. It is the opium of the people” (Shagor, 2005: pp. 1-2).

Accordingly, Marx maintains that it is the psychological state of the oppressed poor in a capitalistic society that gave birth to religion. Hence Townsley (2004) enunciates

...This state, the society produces religion which is the inverted world consciousness because they are inverted world consciousness... Religion produces inverted illusion that the world of religion (the heaven and the gods), are real and the physical world we inhabit as human is a shadow of the real (1-2).

Therefore religion produces an illusionary escape route to the social realities. This spiritual escape though illusionary makes the suffering masses adjust to heinous conditions in this world, in hope of better life in the other world. In the words of Townsley (2005). "Religion makes the poor escape from something that does not care for its people. From a system that dehumanizes workers, and structure that enslaves the people in cycle of oppression" (2-3).

Against this backdrop, Marx maintains that the exploiting classes foster religion in their own vested interest as a means of binding and curbing the popular masses (Uchegbue, 1999: p. 288). Here again, Marx insists that religion is the supreme legitimiztion of the structure of domination in an oppressive society. Religion thus becomes the ideological tool for the dominant classes for the sanctioning and moralizing social evil and exploitations inflicted on the oppressed classes. Marx insists that 
it was to achieve the aim of the oppressors in keeping the oppressed classes perpetually under subjection and persuading them to accepting their conditions as profitable that religion was invented by the bourgeoisies class. Accordingly, religion further acquires a new definition as a body of myths which... provides many of the deceptions which forms the basis of ruling class ideology (Uchegbue, 1997: p. 289).

However, this docility to social and dehumanizing issues, which religion inculcates to its adherents is only one side of the coin. Thus contemporary knowledge as well as scholarship has present to us revolutionary roles which religion played in several oppressive society. The biblical religion of Moses was what initiated the exodus experience of the Jew out of the bondage of Egypt. This may be assigned to the remote history and as such underscored as obsolete. In the more recent days Marx Webber and Emile Durkheim, who with Karl Marx formed the trio pillars of sociology of religion, have presented classical works in which they depicted religion as the most viral institution in bringing about social change and revolution in the recent days. Thus according to contemporary scholarship, religion is an indispensable fact or rather social institution that can challenge the social order and bring about social change.

Notably, the works of the Latin America Catholic Bishop, Don Camara and other Catholic Priests of the same stock, Gustavo Gutierrez, James Cone in South America and in North America, Martin Luther King Jnr, and Malcolm X, In South Africa, we come in contact with Allan Boesak, Desmond Tutu, just to mention. Across the continents, we shall not undermine the works Mahatma Gandhi, who was motivated to carrying out his non violent fight for liberation as across Africa and Asia by his religions convictions.

Though religion is noted to have created docility in the oppressed of any system but also it has also been an active harbinger of revolution in any system. It is in recognition of revolutionary works of religion that Willmore (1973) writes

The black theology is the theology of black liberation. It seeks to plumb the black condition into the light of Gods revelation in Jesus Christ, so that black community can see that the gospel is commensurate with the achievement of black humanity ... The message of liberation is the revelation of God as revealed in the incarnation of Jesus Christ. Freedom is the gospel. Jesus is the liberator (263).

Against the background of this dual position of religion in the society, the paper therefore betook itself to re-examine the roles of religion in the contemporary oppressive society, using the Antebellum America society as our paradigm.

\section{Antebellum America and Slavery}

The enslavement of an estimated ten million African over a period of almost a century in the Atlantic slave was a tragedy of such scope that it is difficult to imagine much less comprehend. when these African slaves were brought to slavery in the mines, the plantations and household of the new world, they were torn away from their political, social and cultural systems that had ordered their lives. Tribal and linguistic group were broken up either on the coast of Africa or in the slave pen across the Atlantic. Most brutal of all, the experiences of the slave trade did not allow the preservation of the kinship ties (Raboteau, 1978: p. 4)

By 1830 slavery was primarily located in South of America, where it existed in many different forms. African-Americans were enslaved on the small farms, large plantations in the cities and towns, inside homes, out in the field and in industry and transportation. Though slavery had such a wide variety of faces, the underlying concepts were always the same. Thus slaves were considered property and they were property because they were black. Notably, the status of a property was enforced by violence-actual or threatened. Being property of their owners, the slaves in the Antebellum America were assigned inferior status. This assumption is sustained by Shade and Roy (1969) as they write, "The generation of white historian writing before 1920 generally recognized the importance of slavery as a causative factor in bringing about the civil war but they presented black men as inferior beings fit only for the most menial tasks even when free" (3). It is against the backdrop of this proposition that James Ford Rhodes, being sympathetic to the right of the white slaveholders believes that modern slavery had proved that the black is distinctly inferior to the white and as such opposed with veracity the efforts of the radical Republicans during Reconstruction. Ulrich Philip on his own, though one of the foremost students of slavery during his years accepted that slavery in the Antebellum America is a system for the social control of an inferior race. William A. Dunining presented his own assessment of the black slaves in South of America thus:

...Gradually, there emerged again the idea of Jefferson and Clay and Lincoln, which had been rooted and hissed into obscurity during the prevalence of abolitionist fever. This was that the ultimate root of the trouble in the south has been, not the institution of slavery but the co-existence in one society of two races so distinct in characteristics as to render coalescence impossible, that slavery had been modus vivendi through which social life was possible and that after its disappearance, it place must be taken by some set of conditions which is more humane and beneficent in accidents, must in essence express the same fact of social inequality ... it seems most improbable that the historian will soon, or ever, have to record a reversal of the conditions which this process has established (Shade \& Roy, 1969: pp. 3-5).

Against this background, Elkin (nd) maintains that the status of slaves in the Antebellum America can only be clearly defined through four legal opsis. In his own words, "the four major legal categorization which define the status of America slaves may be roughly classified as", term of servitude, marriage and family, police and disciplinary powers over slaves and property and civil rights (8). According to the Elkins categorization, the first from which, somehow all others followed, has been in effect since the seventh century. In this situation the Southern law provides that a slave remains a slave for the duration of his life and slavery was a status which he transmitted by inheritance to his children and children's children (Elkins, 1959: p. 52).

The other three categorization belong to what could be noted as jurisprudence of the nineteenth century. By the Nineteenth century, treatment of slavery in the which south took the form of s savagery had been cushioned. Thus we may consider it in the most humane light and at the same time not that the charity with which its basic outlines remained fixed and embodied with modern jurisprudence, much as they had been laid down before the middle of the eighteenth century (Munford, 1909: pp. 101102). Notably, the white Americans look upon a coloured man not as human beings, responsible for the small talent entrusted to him but as a chattel, personal, and as a mere property, no 
better, except in value, than his mule or dog (Logsdon, 1969: pp. 36-37).

However, the slavery law destroyed the institution of marriage and family life and the law never showed any inclination to rehabilitate it. Beecroft (1931) has given an apt description of how the law destroyed the earliest institutional arrangement of man somewhere in his paper thus, “...Here was an area in which consideration of humanity might be expected most widely to prevail and indeed on daily basis they did in the contempt in which respectable society held the slave-trader, who separated mother from child and husband from wife is proverbial in the southern lore" (2.4)

On the surface, the ought to have been simple enough to translate this strong social sentiment into the appropriate legal enactment which might systemically have guaranteed the inviolability of the family and the sanctity of the marriage bond, such as governed Christian polity everywhere (Elkins, 1959: p. 289) However, the very nature of plantation economy and the way in which the basic arrangement of the southern life radiated from it, made it inconceivable that the law should tolerate any ambiguity should the painful clash between humanity and property interest ever occur. Any restriction on the separate sale of slaves would have been reflected immediately in the market, their price would have dropped considerably. Therefore, the law could permit no aspect of the slave conjugal state to have an independent legal existence outside the powers of the man, who owned him. The relation of master and slave is wholly incompatible with even the qualified relation of husband and wife, as it is supposed to exist among slaves. Marriage for them was denied any standing in law. Hence Cobb (1858) admits later, "the contract of marriage not being recognized among slaves and as such none of its consequences follows (246) Elkins (1959) also observes thus:

The relation between slaves, wrote a North Carolina Judge in 1858, is essentially different from that of man and wife joined in lawful wedlock ... for with salves, it may be dissolved at the pleasure of either party, or by the sale of one or both, depending on the caprice or necessity of the owners (10).

The implication of this arrangement is that the offspring of such "concubernal relationship", had next to no guarantees against discriminate separation from their parents, of additional interest according to Elkins (nd) is the fact their children derived their condition from the status of their mother. This was not unique to American slavery but it should be noted that especially in a system conceived and evolved exclusively on the grounds of property, there could be little doubt about how such question would be resolved (12). Had the status been derived from the father's condition, as was the case in the seventeen century Maryland, following the ancient common law, there would instantly have risen the irksome question of what to do with the numerous mulatto children born every year of white planter fathers and slave mothers (Elkens, nd: pp. 12-13). It would have meant that the creation of a free Mulatto class will instantly relieve the master of many salves on the one hand, while burdening him on the other hand with many coloured children, who he could not own. Justifying this position Goodell (1853) writes:

Such equivocal relationships were not permitted to vex the law. That a father of a slave is unknown to our law was a universal understanding of southern jurists. It was thus that a father among the slaves, was legally unknown, a husband without the right of his bed, the state of marriage defined as only that of "concubinage with which alone, perhaps, their condition is compatible and motherhood clothed in scant dignity (106-107).

In fact African-America woman (slaves) had to endure not only threat but also the actual practice of sexual exploitations. They were no legal or otherwise, safeguard to protect them from facing sexual stalked, harassed, or raped or even to be used as along term concubines by their masters and overseers. This abuse was widespread, as the slaveholders took the advantage of their slave situations. Even if a woman seems agreeable to the situation, in reality she had no choice, since slave men, on their own part were powerless to protect their wives and daughter from such abuses. In fact the slaveholders often raped wife and daughters of his slave in his presence to demonstrate his authority over the slave man and to show his powerless and humiliation. Bisssangame (1979) summarized this matter thus:

...slave marriages were illegal in Southern states and slave couples were frequently separated by slave owners through sales, slave owners did have control over the slave marriages. They encouraged monogamous relationships to make it easier to discipline their slaves ... a black man, they reasoned, who loved his wife and children was less likely to be rebellious than a single slave. When a slave couple resides on the plantation, the husband witnessed the whipping and raping of his wife and the sale of his children, remarks that, Nothing demonstrates his powerlessness as much as the slaves inability to prevent the forcible sale of his wife and children (1-7).

On the third category, the police and disciplinary matters, we note that it is difficult not to consider the typical slave lots in the nineteenth century as one of stripes and torture. We should probably not stretch the truth greatly, were we to concede to Ulrich Philip's systematic picture of a just regime tampered paternal indulgence on the majority of well run plantation. Among decent southerners they remark; I was told that he does not use his people well" was a pronouncement of a deep social censure (Elkins, nd: p. 11). However, we notices not only the laxity with which much of the daily disciplines are executed but also the completeness with which such questions, regarding the life and limbs were in fact under the masters control. Debow explains the fact more succintly as he writes, 'We dispenses with whole machinery of public police and public court of justice, thus we try, decide and execute sentences in thousand of cases which in other countries would go into the court' (Elkin, nd: p. 11).

The law noticeable deplored cruel and unusually punishment but whenever, protection was on the one hand theoretically extended, it was practically concealed on other hand by the universal prohibition in the southern law, which enforces that slave has no right whatsoever to testify in court, except against each other and in any case, the courts generally accepted the principle that the line between correction and cruelty was impossible to determine (Adams, 1855: p. 97).

Against this backdrop, a Virginia judge in 1827 faced with an indictment against a master "for cruelly beating his slave" felt bound to decline jurisdiction, with the rhetorical demand: without any proofs that the common law did ever protect the slave from the hand of the master... where are we to look for the power which is not claimed for us. To the jurist, it seems clear on principle that battery of a slave, without special enactment, could not be prosecuted criminally. However, public opinion itself should, since it was generally held, deter wanton brutalities. But the final argument was that if self interest, 
"where the battery was committed by the master himself, there would be no redress whatever. For the reason given in Exodus 21:21, for he is his money. Therefore, the powerful protection of the masters private interest would itself go far to remedy this evil (Cobb, 1855: p. 102).

Even the murder of a slave found the law straining all its reources to avoid jurisdiction. Murder was indeed punishable, but under circumstances peculiar to the state of slavery nor in the way applying to white society and always under the disabilities which barred the testimony of blacks in the court. Similarly, an act of North Carolina in 1798 provided that the punishment for maliciously killing a slave should be the same as a murder of a free person but it did not apply to an outlawed slave or to a slave in the act of resistance to his lawful owner or to slave dying under moderate correction (Elkin, nd: p. 13). The southern Carolina allowed that in the absence of competent witnesses to the homicide of a slave, the affidavit of the accused was admissible in his favour before a jury (Goodell, 1853: p. 180). In the same direction, the criminal jurisprudence of Virginia had never known before 1851 a case of more atrocious and wicked cruelty than that of a man named Souther, who had killed his slave Sam under the most gaudy circumstances, yet the conviction was for murder in the second degree and Souther escaped with five years in the penitentiary. In general the courts primarily care not only in the killing of slave by persons other that the master but in case where the slave himself had committed murder and was executed by the state was pecuniary interest of the owner.

Hence numerous enactments provided for compensation in either event (Hurd, 1854: pp. 297-3007). It was precisely this pecuniary interest, which was at the very heart of legal logic on all such questions. Just as it was presumed to operate against cruel and unusual punishment, so it became virtually a nonsequitor that a man should kill his own slave. The principle has been enunciated very early in this paper, it cannot be presumed that prepensed malice (which alone makes murder felony) should induce any man to destroy his own estate.

The forth and last category to be examined is with regard to the property and all other civil rights of the slaves in that period. With respect to the above named rights, were everywhere denied the slave with a charity that left no doubt of the slaves utter dependency upon his master. The general aphorism is that the slave is in absolute bondage, he has no civil right whatsoever and could hold no property except at the will and pleasure of his master (Ulrich, 1999: p. 115). A slave in Antebellum America can nither give nor receive gifts, he would make no will nor could hire himself out to make contracts for any purpose- even including, as we have seen that of matrimony and as such neither his word nor his bond had any standing in law (Goodell, 1853: p. 32). The common law stipulates that a slave could buy or sell nothing at all, except as his masters agent, He could keep no cattle, horses, hogs, or sheep and in Mississippi, at least could raise no cotton (Goodell, 1853: p. 324).

Notably, even the masters who permitted such transaction, except under express arrangements were uniformly liable to fine (Goodell, 1853: pp. 89-104). It was then obvious that the case of slave who should presume to buy his own freedom, he being unable to possess money would involve as a legal absurdity". Slaves have no legal rights in things real or personal but whatever they may acquire belongs, in point of law to their masters (Goodell, 1853: p. 88).

Such legal stipulations were extended not only over all civic rights but even to the civic privileges of education and worship. In fact every southern state with the exception of Maryland and Kentucky had stringent laws forbidding anyone to teach the slaves reading and writing and in some states, the penalties applied to educating free negroes (Blacks) and mulattoes as well. Teaching of the Blacks both slaves and free is considered to bring the distraction in their state and dissatisfaction in their minds of the slaves and may generally result to slave revolt. In North Carolina for instance, it was criminal to distribute among the slave any pamphlet or book, not extending to bible and the same order applies to the teaching of religion (Harry, 1910: p. 126).

However, the Southern society was not disposed to withholding divine worship from its slaves but the conditions upon which the slaves are to worship would have to be laid down by the slave holder themselves. In the words of Elkins (nd), The conscientious master no doubt welcomed having the gospel preached to his slaves, provided that they should hear it as J. W. Folwer of Coathoma country, Mississippi specified it its originnal purity and simplicity (13). Folwer had written to his overseer that in view of the fanaticism of the age, it behooves the master or overseer to be present on all such occasions, while Alexander Telfeity of Savannah instructed his overseer that there should be no night meetings or preaching allowed on the place, except on Saturday night and Sunday morning (Auther, 1910: p. 27) Similar restrictions were dragged into the state legal system. Typical examples were the acts of South Carolina, which forbade religious meeting of the slaves or free Negroes either or before the raising of the sun or after the setting of the same and the Mississippi permitting slaves if authorized by their masters, to attend the preaching of white ministers.

Generally, the antebellum America considers all slaves as black and slaves are degraded and contemptible, therefore all blacks are degraded and contemptible and should be keep in the state of slavery. Slave status had been defined by the southern jurisprudence as:

...That condition of a natural person, in which by the operation of law, the application of physical and mental powers depends, as far as possible upon the will of another, who is himself subject to the supreme power of the state and in which he is incapable, in the view of the law, of acquiring or holding property and of sustaining those relations out of what relative rights... proceed, excepted as the agent or instrument of another (Goodell, 1852: p. 300).

This definition simply made a slave a property and as such he and his fellow bond had long since become a chattel, personal to all intent construction and purposes whatsoever. It was a horror living as a slave in the antebellum South America. The society was the most oppressive of any human had experienced in the enlightened age. It sounds like a myth but it is a true story of human brutality and cruelty. However, the black survived the ordeal and finally gained their freedom, humanity and personality. Where lies their strength?

\section{Religion of the White in the Antebellum America}

...From the very beginning of the Atlantic Slave trade conversion of the slaves to Christianity was viewed by the emerging nations of the Western Christendom as a justification for the enslavement of Africans (Raboteau, 1978: p. 96)

The Portuguese caravans, who first explored the African interiors returned from the coast of West Africa with human 
booty in the fifteen century. In the assessment of the enterprise, Azurara, a chronicler observed that the enterprise brought greater benefit to the captive Africans more than the adventurers in this case the Portuguese. In his own commendation, he retorted thus, ...For through their bodies were brought into some subjection that was a small matter in comparison of their soul, which now possess true freedom for evermore (Wilmore, 1983: p. 71).

The pangs of guilt over the cruelty in enslaving fellow human beings were assuaged by emphasizing the grace of faith made available to Africans, who otherwise would die as pagans. Azurara's pity was aroused by the tragic scene of a shipload of captives being divided and parceled out to their owners. However, Azurara took consolation in the fact that the slaves must benefit not only spiritually but also materially from contact with Western civilization. In taking this solace Azurara further asserts:

...And so their lot was quite the contrary of what it had been since before they had lived in perdition of soul and body: of souls, in that they were yet pagans, without the clearness and the light of the Holy faith and of their bodies, in that the lived like beasts, without any custom of reasonable beings-for they had no knowledge of bread and wine and they were without covering clothes or the lodgment of houses and worse than all, they had no understanding of good but only know how to live in bestial sloth (Raboteau, 1973: p. 97).

Azurara's inclination which he stated in the mid fifteenth century was to repeat itself or over four centuries by the successive generation of Christian apologist for slavery.

Notably, England, Spain, Portuguese and other Western Christian Europe proclaimed missionary zeal as an important motive for colonizing the new world. The duty of Christianizing slaves as well as Indians was urged upon the Council of foreign plantations by Charles II in 1660 . His instruction to the Council, read in part thus

And you are to consider how such of the natives or such as are purchased by you from other parts to be servants or slaves may best be invited to the Christian Faith. And made capable of being baptized thereunto, it being to the honours of our crown and of the protestant religion that all persons in our dominions should be brought to the knowledge of God and be made acquainted with the mysteries of Salvation. (Jernegan, 1916: p. 508).

Despite the widely held justification of slavery as a means of spreading the gospel and despite the proclamation of the duty of the Christian colonists to evangelize the so called heathen, the process of slave conversion was blocked by major obstacles, not the least of which was the antipathy of the colonist themselves. The economic profitability of his slaves, not their Christianization held top priority for the colonial slaveholders. Accordingly Barbot observes this great roadblock to the conversion of African captives thus

...Christian in America, especially the protestant... take very little care to have their slaves instructed... as if it were not a positive duty incumbent on them by the precepts of Christianity. These provided that the slaves can multiply and work hard for the benefit of their masters, most men are well satisfied without the least thought of using their authority and endeavours to promote the good of the souls of those poor wretched (Raboteau, 1895).

Against this background, Morgan Godwin an English Divine, who spent several years in Virginia, decried the priorities of the colonists in a sermon published in 1685 with title "Trade preferred before religion and Christ made to give place to man" Notably, one of the major reasons for the refusal of the slaveholders to allowing their slaves to receive religious instruction was the fear that baptism would emancipate the slaves (Raboteau, 1973: p. 98). This fear seems to have been predicated on the fact that it is suspected that both the English legal system and the canons of the church had both stipulated that if slaves were baptized they were to be free, though the suspicion was unfounded. Hence, missionaries to the slave had repeatedly complained that the slave owners refused permission to catechize their slaves because baptism made it necessary to free them.

Therefore it seemed that the Christian commission to preach the gospel to all nations runs directly counter to the economic interest of the Christian slave owners. Accordingly the colonial legislation was forged to solve the dilemma. Hence in 1664, the lower house of Maryland asked the upper house to draw an Act obliging the Negroes to serve deveute vita for the preservation of damage the master of such slaves must sustain by such slaves pretending to be Christians. Then by 1706 at least six colonial authorities had passed acts denying that baptism altered the condition of a slave "as to the bondage or freedom".

Even after the colonial authorities had declared baptism to be no threat to the slaveholder's legal right to hold Africans in perpetual bondage, the process of religious instruction which has to proceed baptism was seen by many slaveholders as an economic detachment (Raboteau, 1973: p. 99). This is because the adequate catechization of a slave takes some quality times. Notably the plantation work schedules for the slave gave him little or no leisure for religious instructions. Sunday was the only feasible day for such instruction, yet one of the constant complaints of missionaries was that slaves had to work on the Sabbaths either for their master or when allotted individual plots for themselves

In one occasion in North Carolina, one clergy-Missionary, who was so frustrated had to do a letter to the London Secretary of the Society for the Propagation of the Gospel, making official complaint that many planters, who freed themselves from the trouble of feeding and clothing their slaves allow them only one day in a week to plant for themselves as much as will clothe and subsist for them and their families. The one day in a week allowed was usually Sunday. Even when slaves were not forced to work on the Sabbath, finding time for religious instruction was quite difficult, since the ministers had "work enough from the white folk on his hand".

Nevertheless, owing to the segregated nature and selective teaching of the white religion-Christianity-the slaves frequently used whatsoever leisure time they had for visiting, dancing and merriment activities, which seemed to the missionaries to be an act of profanation of the Lord's Day. Consequently, the missionaries working in South America, being dissatisfied with the problem exhorts the London authority and some governors who in turn made legislation preventing masters from working their slaves on Sunday's or otherwise blocking their attendance at Sabbath (Miller, 1998: pp. 1-7).

However, by the eve of the Civil War, Christianity had pervaded the slave community. This time around, the vast majority of the slaves were American-born. Therefore, the cultural and linguistic behaviours, which seemed to have impeded the evangelization of the earlier generation of African-born slaves, were generally no longer a problem. The widespread opposition of the planters to the religious instruction of the slave had been 
largely dissipated by the efforts of the churches and the missionaries of the South. Nevertheless, it is not all slaves that were Christians, not were all those who accepted Christianity members of the church, yet the doctrines, symbols and vision of life preached by Christianity were familiar to most of them (Raboteau, 1973: p. 213) Noll (2006) gave an idea of the statistics of the church and churchmanship within this period as he writes:

At the start of the civil war, there were more than 53,000 churches in the United States. Although only about 40 percent of the nation's almost 32 million people were formal church members of organized faith traditions, as many as 80 percent of American visited Catholic or denominational protestant churches regularly (1-7).

Within this period, the church was not only a spiritual centre but also a socio-cultural rendezvous. Affirming this position Noll (2006) writes "In addition to inculcating personal faith beliefs, the churches acted as important agent of culture, since there were no televisions, no movies or telephones and certainly no internet to inform Americans in their development as citizens” (1-7). Within the period of Antebellum and Civil War, Churches along with families and communities, were primarily, means through which gender and racial roles were outlined and civil knowledge delivered. The Civil war religiosity was not confined to walls of the local meeting houses but permeated Northern and Southern Secular Society. Thus Noll (2006) asserts further, "by 1860, religion had reached a higher point of public influence than at any previous time in America history" (1-7).

Religion within this period was an instrument to defend the institution of slavery in the South. The defense was forged by protestant clergyman and predicated on the biblical validity of the institution. Southern slaveholders, moreover used biblical catechism in their efforts to control the enslaved. The testimony of a former slave, Charlie Dyke justifies this claim as he complained openly thus.

Church was what they called it but all the preachers talked about were for us to obey our masters and not to lie and steal. Nothing about Jesus was ever said and the overseers stood there to see the preacher talked as he wanted him to talk ... Even the black preacher would get up to repeat everything that the white preacher had said because he was afraid to say anything different (Cade, 1935: p. 329).

Frank Rebertson also paraphrased the kind of sermon they were subjected to listen to as slaves.

You slaves will go to heaven if you are good but do not ever think that you will be close to your mistress and masters No! No!, there will be a wall between you, but there will be holes in it that will permit you to look out and see your mistress when she passed by. If you want to sit behind this wall, you must do the language of the text; obey your masters (Noll, 2006: pp. 1-7).

Lucretia Alexander explained what slaves did when they grew tired of the white folks preachers.

The preachers came and... had just say, serve yours master. Don't steal your master's turkey, Don't steal your master's Chickens Don't steal your masters hawks, Don't steal your masters meat. Do whatsoever your master tells you to do. Same old thing all the time, the fathers would have church in dwelling houses and they had to whisper ... sometimes they would have church at his house. That would be what they would want a real meeting with some real preaching... They used to sing their songs in a whisper and pray in whisper. That was a prayer meeting from house to house once or twice a week (Noll, 2006: pp. 1-6).

The slaves, notably, frequently were inundated to hold their meetings out of the disgust for the vitiated Gospel preached by their masters' preachers, sermon urging them to be obedient and docile were repeated and ad nauseam. This was the motivation and origin of slave religion in Antebellum America.

\section{The Religion of the Slaves in the Oppressive Antebellum Society}

Born in slavery, weaned in segregation and reared in discrimination, the religion of the Negro folk was chosen to bear the roles of both protest and relief. Thus, the uniqueness of black religion is the racial bond which seeks to risk its life for the elusive but ultimate goal of freedom and equality by means of protest and action (Wilmore, 1973: p. 38).

Actually, the religion of the black people in the United States within the period of our study is unquestionably predisposed to the beliefs and practices associates with the Judeo-Christian traditions. However, the Christianity which had developed for more than four hundred years among the descendants of the first African slaves brought to the New World is a different version of the Christianity which was professed by the slave masters. Raboteau (1978), gave a brief historical antecedent to the origin, nature and essential influence of the black religion in America as he write:

...The Gods of Africa were carried in the memories of enslaved African across the Atlantic to be sure, they underwent a sea of change. African liturgical seasons, prescribed rituals traditions, myths and language of worship were attenuated, replaced and altered or lost, still much remained and particularly in Latin America, the Gods lived on in the beliefs and rituals of the slave descendants (16).

Consequently, in many part of the South America, for instance in Georgia, slave had a religion of their own based on their own experience, the experience of God with them and upon various visions and revelations. Though most of the slaves, especially those who associated themselves with the Western Christianity respected the Bible and learned to read it before they would read anything else, however, among the slaves there were general contempt for book "book religion" not merely because they possessed a great self esteem and confidence in their own manner of believing and worshiping God (Reek, 1982: pp. 153-196), since for them, the spirit within was superior to the Bible as a guide to religious knowledge.

In the light if this assumptions, the slaves as far back as 1774, were declaring publicly and political that they thought that Christianity and slavery were compatible. The slaves made frantic attack on the slaves holding Christianity as they clamed that slaves knew enough of the orthodox theology of the time to consign all bad slaveholders to hell and on the same direction maintain that heaven would not be heaven unless slaves would be avenged on their enemies (Goodell, 1931: p. 5200).

However, the slaves did not reject Christianity out rightly; they simply made adaptation to Christianity that rendered it something more than a dispassionate system of belief and code of pious behaviour. The slaves accepted on the one hand, the spirited, revivalist interpretation of the impassionate Methodist and Baptist Missionaries and imitated them but on the other hand, went far beyond their understanding of Christianity to fashion it to his own sense and recreational as well as personal 
and spiritual needs.

The slaves were conscious of the fact that in the new world, the major aim of slave control was to eradicate all forms of African culture, which according to the African-American slave has the capability to unify the slaves and empower them to resist or rebel against their situation of slavery and its perpetrators. Therefore, they expatiated all spiritual and moral energies to keep African beliefs and customs a life and accordingly transmitted them to their descendents.

The African culture in the New World underwent several transmutations and as such having being shaped and modified by the new environment, its basic elements of folklore, music, language and religion were sustained in the New World by the African in Diaspora. Influenced by the Colonial European and indigenous Native American cultures, aspects of African heritage have contributed immensely to the formation of various Afro-American cultures in the New World. Notably, one of the most durably and adaptable constituents of the slave culture linking African past with American present, was his religion. It is therefore important to realize that in the America, the religions of Africa have not been merely preserved as "static" Africanism or as archaic "retentions", but they have continued to develop, putting new roots in the new soil, bearing new fruit as unique hybrids of American origin.

African styles of worship, forms of ritual, systems of belief and fundamental perspectives, have remained vital on the New World, not because they were preserved in a "pure" orthodoxy but because they were transformed. Adaptability based upon respect for spiritual powers, wherever it originated, accounted for the openness of African religions to syncretism with other religious traditions and for the continuity of distinctively African religions consciousness. At least in some areas of the Americas, the African Gods have continued to live in exile. Reiterating this assumption Swatos (2011) writes:

Despite the presence of Africanism in African American religion, such as the call and response pattern characteristics of black preaching, it is evident that no single African culture or religion could have been diffused intact to North America. African religions concepts and rituals such as ancestor worship, initiation rituals, spirit possession, healing and formal rituals, magical rituals for obtaining spiritual powers and ecstatic ceremonies enshrined by rhythmic dancing, drumming and singing are found in African American religion but generally in syncretized ways, blended with diverse European-American elements (1-17).

According to Swatos (2011), prior to the American Revolution very few slaves were genuine Christians, other than in a nominal sense. Most slaveholders were reluctant to foster the conversion of their slaves to Christianity because they feared that it might provide than with notions of equality and freedom. With the passage of time, the slaveholders became convinced that a selective interpretation of the gospel would foster docility in their slaves (Baer \& Singer, 1992: p. 42).

However, the slaves took note that Christianity alone as presented to the slaves, adulterated, other worldly and disengaged from its most radicals implications, could not have provide them with the religion needed for revolt, it had to be enriched with the volatile ingredients of African religious perspectives and, most importantly, with the profound human yearning for freedom that found a channel for expression in the survival of African religions resident in the early black Churches in Latin America. Concerning the origin of this black church which adopted the elements of both Christianity and African religious traditions, Scheiner (1969) maintains.

The Negro Church came into being in the history of the United States... first as an invisible institution on the Southern plantation, secondly as a reaction to discrimination in the white churches. It was this latter practice which led many blacks in the Northern Urban centers to organize their own houses of worship (197).

Scheiner (1969) described the black church in two categories as both invisible and visible institutions. It might seem strange that an institution such as church would be described as invisible. However, this is a true and apt description of the black church in the Southern America, noting that in independent black churches with slave members in attendance never existed in the South before the emancipation. In the racially mixed churches, it was noted that slaves outnumbered masters in attendance at every Sunday service. However, the religious experiences of the slaves by no means were fully contained in the visible structure of the institutional church. Therefore the slaves had to find means of containing their spiritual needs, hidden from the notice of their masters/Thus in the secrecy of their quarters or seclusion of the bush or bars the slaves made Christianity their own.

Therefore, regular Sunday worship in local church was paralled by the seeming illicit or at least informal prayer meetings on week night in the slave cabins. Preachers licensed and hired by the masters were supplemented by slave preachers licensed only by the spirit. Text from the Bible which slaves would not read was explicated by verses from the spirituals. Often such meetings were organized in the night and most often last all through the night. It was in this all night singing and praying that the slaves pour out their suffering and needs of the day. Wilson (2011) writes, like "steal away" and the test for spirituality, Christianity has failed the slave community to satisfying its own particular experience. At the same time, the symbols, myths and values of Judeo-Christian traditions helped form the slave community's image of itself (214).

In the slave's secret payers/religious meetings everybody's heart was in tune and when they called on God, the more heaven rings, it was more than just Sunday meeting and then no godliness for the week (Blassinegame, 1973: pp. 13-14). According to one ex-slave account, they would steal off to the field and in the thickets and there they called on God out of heavy hearts. It was truly communal, these meeting needed often no preachers because, everyone was anxious to have a word to say that preacher had no chance. All of them would sing and pray (Blazssnyane, 1973: p. 15). A description of secret meeting prayer meeting was recorded by Randolph, who was a slave in Prentice George County, Virginia until he was freed in 1847.

Not being allowed to hold meeting on the plantation, the slaves assemble in swamp, out of reach of the patrols. They had the understanding among themselves as to the time and place of getting together. This is often done by the first one arriving breaking boughs from tree and bending them in the direction of the selected spot. Arrangement are made for conducting the exercise. The first ask each other how they feel and the state of their minds etc. The male members then select a certain space in separate groups, for the division of the meeting, "preaching ... by the brethren, the praying and singing all around until generally they feel quite happy. The speaker usually commences by calling himself unworthy and talks very slowing until 
feeling the spirit he grows excited and in short time, there fall to the ground, twenty or thirty men and woman under its influence (Rabotaeu, 1963: p. 217).

This meeting had great impact on the life of the slave community. In such secret meetings the slaves forget their sufferings except, however reminding others of the trials during the past week, in which they often exclaimed, "Thank God, I shall not live here always". They then pass from one to another, shaking hands and bidding each other farewell. As they separate, they sing a parting hymn (Blassangnue, 1973: p. 20). Notably, prayer, preaching, song, communal support and especially, feeling the spirit refreshed the slaves and consoled them in their time of distress. They imagining their lives in the context of a different future, the slaves gained hope in the present. Accordingly the context between present pain and future relief formed the basic issue in the slave prayers and song. The slaves sought consolation in the future but they also found it in the present. Exhausted from a day of work that stretched from "day clean" to sundown, the slaves sometimes found tangible relief in prayers.

Freedom was frequently the object of prayer. According to Laura an Ex-slave, “some believed they'd get freedom and others didn't (Blessingmane, 1973: p. 22). Actually, in every prayer meeting, they always prayed for freedom some of them believed it would come in their life time here on earth, while others believed that freedom had simply, an eschatological dimension, while the skeptics even among the slaves believed it was foolishness expecting such freedom on the context of present circumstances.

The religion of the black from invisible nature grew to become a visible institution that affected the American society of the Antebellum period radically. Swatos (2011) gave a historical antecedent that gave birth to the emergence of black church as he writes:

Although black people in the North America never enjoyed complete religions autonomy during the antebellum period, relatively independent African America congregation and religious associations emerged at this time. Early modern Baptist churches such as the Joy Street Baptist Church in Boston (established in 1805) and the Abyssinian Baptist church in New York (established in 1808) appear to have emerged as a protest to discrimination in racially mixed church (1-7).

Scheiner (1969) explicated more the on protest against discrimination by the Negroes in the mixed congregation as he writes further

...it was the practice of discrimination in white churches that led many blacks in Northern urban centers to organize their own houses of worship. For example a group of Philadelphia Negroes had attended a predominantly white Methodist church without incident until November, 1897. On a Sunday in that month, the church's leaders attempted to seat the blacks in the rear or the gallery, refusing to abide by the practice, the blacks led by Richard Allen and Absalom Jones left the church and organized the free African Society (23).

This was the emergence of black church that was until then an invisible institution into the public sphere. The two leaders Richard and Jones soon parted ways. Jones established the first independent Northern Negro Church-St. Thomas Protestant Episcopal Church of Philadelphia, while Richard founded the Bethel African Methodist Episcopal Church in Philadelphia, dedicated in 1794. Other Negro Methodist followed Richard's example and organized A.M.E churches in other cities and in
1816, they joined together in a National African Methodist Episcopal Church (Scheiner 1969: 98)

However, the independent Negro church movement expanded beyond the Methodist church. Among the separated Negro churches were; Abyssinian Baptist and St. Phillip’s Protestant Episcopal Churches in New York City, Africa Baptist Church in Philadelphia and African Congregational Church, New Haven. were all founded within this period While some blacks still retained their membership in predominantly White churches, a majority affiliated with Negro houses of worship.

Born in protest, the black church, prior to the civil war represented the initial stirring of black rebellion among both the secret religions congregations of the slave community and the openly organized independent black churches and the religious mutual aid societies of Freeman in the North, consequently moving between the two poles of immediate survival and future liberation (Charles, 1998: p. 72) The Religion of the blacks, whether in the "invisible" or "visible" forms cultivated the spirit of upliftment and self expression and laying the foundation of black powers and self determination.

Through their Religion, these slaves understood that the Christian Gospel was a gospel of liberation and this understanding caused them to refuse to accept an interpretation of Christianity that was unrelated to their civil freedom. This fundamental religious faith brought strength and encouragementto each of them. Regardless of denomination, the black church was the centre of community, hope and solace for the faithful. It spoke out on the issue of slavery without fear and supported the fight for freedom, equality and justice. At the beginning of the civil war, Black churches had no hesitation bearing witnesses against slavery. "They were sanctuaries for fugitives from slavery and played important role in establishing channels of communication between anti-slavery groups and the enslaved African-Americans (Billingsley, 1999: pp. 24-34).

As black congregation grew, the continued to serve as meeting houses for anti-slavery rallies. They became powerful instrument in helping the enslaved make their way to freedom through a network of escape routes and secret flight strategies, known as the "underground railroad". Although a complex and dangerous undertaking the black church, along with the antislavery party lent support by providing physical, material and financial aid to achieve their goal.

The black church not only provided the survival and liberation strategies that allowed freemen and the enslaved to sustain the slaves escape but also supported the recruitment of black soldiers in the face of intense racial prejudice. Notably, during the civil war black soldiers were anxious to join the fight against slavery. In doing so, they hoped that their military service would gain them freedom, voting right and the right to full citizenship (Billingsley, 1999: p. 17). Arguing that military service would prove their right to citizenship and guarantee the right to vote, Douglas Frederick was a strong advocate of allowing black men to fight in the civil war. Douglas believed that it would be a matter of survival for freed Blacks in the South and he along with other black abolitionists often used the black church to delivers their freedom messages. There they challenged Christians to confront an institution that violated the central tenet of the Christian faith, including the principle of equality before God.

The black church has along history of anti-slavery and other political activities, undergirded by collective faith, it was fertile ground during the American civil war for the freedom move- 
ment among both the enslaved and the freemen. Despite the brutality and dehumanization of the slaves, it was in their church that the blacks sought to exercise their powers and to control their own affairs (Jone, 1970: p. 49). In the church, the blacks had a sense of individual values that contradicted the devaluing and dehumanizing forces of slavery. As the hub of increasing economic powers, the black church was a reservoir of strength and purposes for those engaged in the struggle for emancipation and civil equality. The emancipation proclamation signed by Abraham Lincoln on January, 1 1863, seemed to re-enact the exodus story of the ancient Israelites. God had intervened once more in human history to liberate his chosen people just as in the time at Moses and the Egyptian slaves. The exodus was about a collective faith-a collective deliverancethe exodus was also about freedom. The enslaved survived because they had believed in the eventual justice of a benevolent God.

\section{Conclusion}

We have taken some time out to re-examine the role or religion in any oppressive society, and discovered that religion is a strong social instrument that could be manipulated for whatever purpose. The oppressor could apply the mechanism of religion to subdue the oppressed and enslave the poor perpetually. Therefore in Marx category religion plays the role of opium for the people-making them docile and causing them to think that their material and existential realities have eschatological dimensions

On the other hand, religion can be used as a virile instrument to challenge an oppressive society. Religion is an institution that equips those who use it for social reforms of the oppressive society, with moral, spiritual and collective powers that no other weapon on earth can challenge. It was the religion of the black people in the Antebellum American that broke the chains of slavery and bequeathed the American society of after war period with conscience. Religion is the greatest weapon with which to fight oppression.

\section{REFERENCES}

Adams, N. (1855). A Smith of view of slavery. New York: Pittman.

Baer, H.A., \& Singer (1992). African-American religion in the twenty century. Knox Ville: University of Tennessee Press.

Beecroft, F. (1931). Slave trading in the old south. Baltimore: $\mathrm{J} / \mathrm{H}$. Hems.

Billingsley, A. (1999). Mighty like a river: The black church and social reforms. New York: Oxford University Press.

Blassingame, J. W. (1973). Black New Orleans 1860-1890. Chicago: Chicago University Press.

Blassingame, J. W. (1998). The slave community (revised ed.). Mary Knoll: Charity Books.

Cade, J. B. (1935). Out of the mouths of the ex-slaves. Journal of Ne- groes History, 20, 394-337. doi:10.2307/2714721

Christian, K. J. (2008). Sociology of religion and contemporary development. Lamlam, MD: Rowman and Littlefield Publishers.

Cobb, T. R. R. (1858). An Inquiry into the law of slavery in United States of America. Philadelphia: J. J. W. Johnson.

Elkins, S. M. (1959). Slavery: A problem in American institutional and intellectual life. Chicago: University of Chicago Press.

Elkins, S. M. (nd). Slavery in capitalist and non-capitalist cultures. In L. Foner, \& E. D. Genovese (Eds.), Slavery in the new world. Englewood Cliffs, NJ: Princeton Hall Inc.

Goodell, W. (1853). The American slave code in theory and practice. New York, NY: America and Foreign Anti-Slavery Society

Harura, J. (1910). The negro in the new world. London: Methuen.

Hurd, S. G. (1851). The law of freedom and bondage. New York, NY: Harpers Brothers.

Jernegam, M. W. (1916). Slavery and conversion in American colonies. America Historical Review, 21, 504-527. doi:10.2307/1835009

Logsdon, J. (1969). Diary of slave recollection and property. Seven on Black: Reflection of Noges. Philadelphia: J. B. Lepinccott.

Lone, J. H. (1970). Black consciousness and the black church: A historical theological interpretation. The Annals of the American Academy of Political and Social Sciences, 23.

Mellowes, M. (2010). God in American: The black church. http://www.pbs.org

Miller, R. M. (1998). Religion and American Civil War. Oxford: Oxford University Press.

Munford, B. B (1909). Virginia's attitude towards slavery and secession: New York, NY: Longman.

Noll, M. (2006). The civil war as a theological crises. Chapel Hill: University of North Carolina.

Raboteau, A. J. (1978). Slave religion: The invisible institutions in the antiebellum south. Glasgow: Oxford University

Randall, M. M., Stout, H. S., \& Charles, R. (Eds.) (1998). Religion and the American Civil War. Oxford: Oxford University Press.

Reek, G. R. (1982). Black radical consciousness and black Christian experience. Sociological Analysis, 43, 153-169.

Scheiner, S. M. (1969). The church and the north city 1890-1930. In W. Shade, \& R. C. Herenkohl (Eds.), Seven on Black: Reflections on the negro experience in America. Philadelphia, PA: J. B. Lippincott Company.

Shade, W. G., \& Herrenkohl, R. C. (1969). Seven on black: Reflections on the negro experience in America. Philadelphia, PA: J. B. Lippincott Company.

Shagor, H. (2005). Marx and religion: A brief study. New York: Orbiss Books.

Swatos, W. (2011). Encyclopedia of religion and society. Hartford: Institute for Research, Hartford Seminary.

Townsley, J. (2004) Marx, Webber and Durkheim on religion. New York: Orbiss Books.

Uchegbue, C. (1997). Karl Marx Theory of Religion. In G. O. Ozumba (Ed.), The great philosophers (Vol. 2). Aba: Vitalis Books.

Ulrich, P. B. (1999). A documentary history of American industrial society. Cleverland: Aunther H. Clark.

Wilmore, G. S. (1983). Black religion and black radicalism. New York, NY: Mary Knoll.

Wilmore, G. S. (1973). Black religion and black radicalism: An examination of the black experience in religion. New York: Anchor Books. 